\title{
Precipitation of Calcium Phosphates in the Presence of Collagen Type I on Four Different Bioactive Titanium Surfaces: an in Vitro Study
}

\author{
Victoria F. Stenport ${ }^{1}$, Julia Olander ${ }^{1}$, Per Kjellin ${ }^{2}$, Fredrik Currie ${ }^{2}$, Young-Taeg Sul, Anna \\ Arvidsson ${ }^{1,3}$ \\ ${ }^{1}$ Department of Prosthetic Dentistry/Dental Materials Science, Institute of Odontology, The Sahlgrenska Academy, University \\ of Gothenburg, Göteborg, Sweden. \\ ${ }^{2}$ Promimic AB, Göteborg, Sweden. \\ ${ }^{3}$ Dentsply IH AB, Mölndal, Sweden.
}

\author{
Corresponding Author: \\ Victoria Franke Stenport \\ Department of Prosthodontics/Dental Materials Sciences \\ Institute of Odontology, The Sahlgrenska Academy \\ University of Gothenburg \\ Box 450, S-450 30 Göteborg \\ Sweden \\ Fax: +46317863193 \\ E-mail: victoria.stenport@odontologi.gu.se
}

\begin{abstract}
Objectives: To compare the properties of calcium phosphate precipitation on four different bioactive surface preparations and one control surface in the simulated body fluid model with added collagen type I.

Material and Methods: Blasted titanium discs were treated with four different surface modifications, alkali and heat, sodium fluoride, anodic oxidation and hydroxyapatite coating. The discs were divided into five groups where one group, the blasted, served as control. The discs were immersed in simulated body fluid and collagen for $24 \mathrm{~h}, 3$ days, 1 week and 2 weeks and then analysed by optical interferometry, scanning electron microscopy/energy dispersive X-ray analysis and X-ray photoelectron spectroscopy.

Results: All surfaces show small precipitates after 3 days which with longer immersion times increase. After 2 weeks the surfaces were completely covered with precipitates, and $\mathrm{Ca} / \mathrm{P}$ ratios were approximately 1.3 , independently on surface preparation. The fluoridated discs showed significantly $(\mathrm{P} \leq 0.05)$ higher degree of $\mathrm{CaP}$ after one week of immersion as compared to the other surface preparations. The collagen type I content increased with time, as reflected by increased nitrogen content.

Conclusions: The results from this study indicate that a fluoridated titanium surface may favour precipitation of calcium phosphate in the presence of collagen type I, as compared to the other surface treatments of the present study.
\end{abstract}

Keywords: biocompatible materials; collagen type I; dental implantation; titanium.

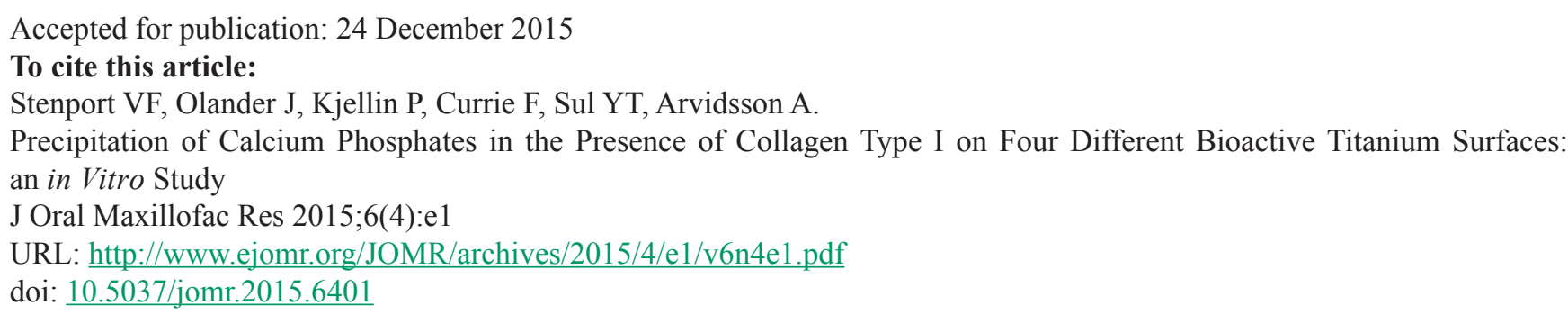




\section{INTRODUCTION}

Since more than a decade it has been suggested that surface modified titanium implants may obtain their bone anchorage via both biomechanical and biochemical anchorage mechanisms [1,2] The bond is in all probability predominantly biomechanical. However biochemical bonding is potentially obtained by bioactive implants. Hench [3] has defined bioactivity as "the characteristic of an implant material which allows it to form a bond with living tissues". Surface modified titanium implants may thus show bioactive properties. The surface modification can be obtained by chemical or biochemical (i.e. protein coating) treatment [4]. Alkali and heat treated titanium plates have been found to resist much higher failure loads than non-treated controls [5-7]. Moreover, some studies have presented evidence that titanium implants oxidised in a calcium hydroxide solution likewise become bioactive [ㅁ] . The wettability of the implant surface is also of importance for early osseointegration, where a more hydrophilic surface is suggested to generate a stimulating effect on healing and tissue integration to the implant surface [9]. Theoretically, the advantage with bioactive implants is that biochemical attachment is rapid and occurs at the interface, i.e. it acts at a time when proper biomechanical interlocking has not yet been developed, and initiate bone induction on the implant surface. Still, little is known about the biochemical bond at the chemical level of possible bioactive implants. The surface roughness on the implants are also of interest regarding possible ossification and it has been suggested in a systematic review on surface roughness and its effect on bone healing that a higher bone to implant contact was seen with higher surface roughness [10].

One in vitro model extensively used to investigate bone formation is immersion of the biomaterial in simulated body fluids (SBF), solutions with ion concentrations approximately equal to those of human blood plasma [11-16]. Depending on the nucleating capacity of the material, bone-like calcium phosphates have precipitated onto the surface. Immersion time is one factor found to influence the amount, and the crystalline degree, of the calcium phosphate precipitate [17]. Titanium surfaces modified with different preparation techniques have different surface properties, and it can be hypothesized that the different surfaces will exhibit different nucleating abilities. Alkali and heat treatment [18], anodic oxidation [19], fluoridation [20], and hydroxyapatite coatings [21] are all titanium treatments that have been suggested to produce bioactive surfaces. The actual bond has not been shown, but different indications for bioactivity have been presented. For example, when fluoridated or anodically oxidised implants have been removed from rabbit bone, the rupture has generally occurred in the bone tissue and not at the bone to implant interface $[19,20]$. Other researchers have evaluated bioactivity by examining nucleation and growth of apatite after immersion of implants in SBF [11]. In a review by Kokubo and Takadama [22] it was concluded that there is a correlation between apatite formation in SBF and in vivo bone bioactivity.

Arvidsson et al. [23] compared the formation of calcium phosphates on titanium implants with four different surface preparations by using the SBF model. A difference in the precipitation of calcium phosphates was shown between the controls and the bioactive surface types, as well as between the different bioactive surface types [23]. Recent studies have shown that four different bioactive surfaces induce faster nucleation of calcium phosphate compared to a blasted control surface in the presence of both albumin [24] and fibrinogen [25]. It was also indicated that the albumin coverage on the titanium was more rapid on the bioactive surfaces as measured in content of nitrogen [24].

Collagen is the most abundant protein in the body $[\underline{26}, \underline{27}]$. The collagens are a large family of proteins, containing at least 19 different members. They are characterized by the formation of triple helices in which three polypeptide chains are wound tightly around one another in a rope-like structure. Collagen type $I$ is the most abundant collagen type of the human body and plays an important role in bone formation as the main organic component of bone tissue [27]. This protein is of interest because of its reported action in signal transduction and modulation in cell adhesion [ $\underline{28}, \underline{29}]$. Collagen type I has also been claimed to have osteoconductive properties. Collagen on the implant surface has been reported to activate fibroblasts around the implants, favour cell adhesion to the implant surface [30], and stimulate the growth on osteoblasts adjacent to the implants [31]. In one study it was suggested that collagen coated titanium implants enhanced early bone remodelling and a tendency towards increased bone formation around the implants were reported [32].

In an in vivo study on nasal reconstruction using a collagen type I gel matrix it was concluded that collagen type I gel positively influenced the bone repair in large nasal defects, which showed minimal bone closure in untreated controls [33]. 
The aim of the present study was to compare the properties of calcium phosphate precipitation and protein adhesion on four different bioactive surface preparations and one control surface in the simulated body fluids model. The bioactive properties of the surface preparations included in the present study have earlier been described [18-21,23]. The hypothesis was that the presence of collagen type $I$ in the simulated body fluids solution would favour precipitation on the bioactive surfaces.

\section{MATERIAL AND METHODS Surface preparations}

In total 75 circular discs (Ø: $8 \mathrm{~mm}$, thickness: $3 \mathrm{~mm}$ ) of commercially pure titanium (grade 3 ) were included in the present study. The specimens were blasted with $\mathrm{Al}_{2} \mathrm{O}_{3}$ powder with a particle size of 75 $\mu \mathrm{m}$, to increase the surface roughness. The samples were ultrasonically cleaned in diluted Extran MA01 and absolute ethanol, respectively, and dried at $60^{\circ} \mathrm{C}$ for 24 hours. The discs were then divided into five groups, one group $(n=15)$ served as a control and was not subjected to any surface treatment prior to the SBF immersion. The other groups of samples were used for the following surface preparations.

\section{Alkali and heat treatment}

Alkali and heat treatment was performed as described in the literature $[18,33,34]$. The specimens $(n=15)$ were soaked in $5 \mathrm{M}$ aqueous sodium hydroxide $(\mathrm{NaOH})$ for 24 hours at $60{ }^{\circ} \mathrm{C}$ and were thereafter gently washed with distilled water before they were let to dry for 24 hours at $40{ }^{\circ} \mathrm{C}$. The specimens were then heated in air to $600{ }^{\circ} \mathrm{C}$ by increasing the temperature by $5{ }^{\circ} \mathrm{C} /$ minute in an electrical furnace (Bitatherm, Bita Laboratory Furnaces, Israel), and were kept at $600{ }^{\circ} \mathrm{C}$ for 1 hour before being allowed to cool to room temperature in the furnace.

\section{Anodic oxidation}

Samples $(n=15)$ were prepared in a mixed electrolyte containing magnesium ions using the Micro Arc Oxidation (MAO) method in galvanostatic mode [35]. The electrochemical cell was composed of two platinum plates as cathodes and the titanium anode at the centre. Currents and voltages were continuously recorded at intervals of one second by an IBM computer interfaced with a DC power supply. The content of ripple was controlled to less than $0.1 \%$. The surface properties of the oxidised group were characterised as a magnesium titanate consisting of 9 atomic $\% \mathrm{Mg}, 3.4 \mathrm{~lm}$ of oxide thickness, $24 \%$ porosity of porous structure, and anatase plus rutile of crystal structure [하] .

\section{Fluoridation}

One group of samples $(\mathrm{n}=15)$ was fluoridated according to the technique of Ellingsen [20]. The samples were immersed in an aqueous solution of $0.95 \mathrm{M}$ sodium fluoride $(\mathrm{NaF})$ and subsequently washed twice in distilled water for 30 seconds. The samples were then allowed to dry at room temperature.

\section{Hydroxyapatite coating}

A hydroxyapatite coating was obtained by spincoating the titanium discs $(n=15)$ with a stable sol which contained surfactants, water, organic solvent and crystalline nanoparticles of hydroxyapatite with a $\mathrm{Ca} / \mathrm{P}$ ratio of 1.67 . The diameter of the hydroxyapatite particles was approximately $10 \mathrm{~nm}$. After the spincoat procedure the discs were dried for half an hour in open air, allowing the organic solvent to evaporate. This was followed by a heat treatment at $550{ }^{\circ} \mathrm{C}$ for 5 minutes under oxygen enriched atmosphere in order to remove all dispersing agents. The treatment resulted in a very thin hydroxyapatite coat on the titanium surface (less than $50 \mathrm{~nm}$ thick).

\section{SBF immersion}

The revised SBF (r-SBF) described by Oyane and co-workers [37] was used in the present study. It was prepared by dissolving $5.403 \mathrm{~g} \mathrm{NaCl}$ (Merck, Darmstadt, Germany), 0.74 g $\mathrm{NaHCO}_{3}$ (Merck, Darmstadt, Germany), 2.046 g $\mathrm{Na}_{2} \mathrm{CO}_{3}$ (Merck, Darmstadt, Germany), 0.225 g $\mathrm{KCl}$ (Merck, Darmstadt, Germany), 0.23 g $\mathrm{K}_{2} \mathrm{HPO}_{4} \cdot 3 \mathrm{H}_{2} \mathrm{O}$ (Merck, Darmstadt, Germany), $0.311 \mathrm{~g}^{\mathrm{MgCl}_{2}}$. $6 \mathrm{H}_{2} \mathrm{O}$ (Merck, Darmstadt, Germany), $11.928 \mathrm{~g}$ 2-(4-(2-hydroxyethyl)-1-piperazinyl) ethanesulfonic acid (HEPES) (Research Organics Inc., Cleveland, Ohio, USA), $0.293 \mathrm{~g} \mathrm{CaCl}_{2}$ (KEBO Lab AB, Spånga, Sweden), and $0.072 \mathrm{~g} \mathrm{Na}_{2} \mathrm{SO}_{4}$ (Merck, Darmstadt, Germany) in $1000 \mathrm{ml}$ distilled water. HEPES was dissolved in $100 \mathrm{ml}$ distilled water before being added to the solution, and the final $\mathrm{pH}$ was adjusted to 7.4 at $37{ }^{\circ} \mathrm{C}$. Collagen solution (type I, bovine, SigmaAldrich Company, UK) was added result in a final concentration of $10 \mu \mathrm{g} / \mathrm{ml}$.

Each specimen was immersed in $25 \mathrm{ml} \mathrm{r-SBF/collagen}$ in separate sealed polystyrene vials and kept at $37^{\circ} \mathrm{C}$. 
Once every week the r-SBF/collagen was changed to freshly prepared solution. After immersion for 24 hours, 3 days, 1 week and 2 weeks, the SBF/collagen immersion was interrupted and the specimens were thoroughly rinsed with distilled water to remove any loosely attached calcium phosphate material. The specimens were then dried at room temperature and sealed in dry vials. Three of each type of surface samples (with the exception of the fluoridated control group, which consisted of two samples) was not immersed in SBF/albumin, to serve as controls for each type of surface group.

\section{Surfaces analysis \\ Topographical characterization}

All specimens were topographically analysed after SBF immersion with an optical interferometer (MicroXam $^{\mathrm{TM}}$, PhaseShift, Tucson, Arizona, USA). The specimens of each surface type that were not immersed in SBF were also analysed, and were used as controls.

The instrument has a vertical resolution of $0.05 \mathrm{~nm}$ and horizontal resolution of $0.3 \mathrm{~mm}$.

Each disc was measured in one area, located in the corresponding region for all discs regardless of group using a 50 times magnification objective and a zoom factor of 0.62 resulting in a measuring area of $200 \mathrm{x}$ $260 \mu \mathrm{m}^{2}$.

A Gaussian filter sized $50 \times 50 \mu \mathrm{m}^{2}$ was used to remove shape and waviness before surface roughness was calculated.

Thereafter the surface roughness, in terms of the following topographical parameters, was calculated:

- $\mathrm{S}_{\mathrm{a}}=$ Arithmetic mean height deviation from a mean plane $(\mu \mathrm{m})$.

- $\mathrm{S}_{\mathrm{ds}}=$ Density of summits, i.e. the number of summits of a unit sampling area $\left(\mu \mathrm{m}^{-2}\right)$.

- $\mathrm{S}_{\mathrm{dr}}=$ Developed interfacial area ratio, i.e. the ratio of the increment of the interfacial area of a surface over the sampling area (\%). In other words, the increased surface area.

Mathematical descriptions of the parameters can be found in Stout et al. [38].

Calculations of group means and standard deviations for each surface preparation and time point were performed.

\section{Scanning electron microscopy/energy dispersive $X$-ray analysis}

For the scanning electron microscopy (SEM) analyses, a LEO Ultra 55 FEG SEM equipped with an Oxford Inca EDX system, operating at $7 \mathrm{kV}$, was used. The samples were examined without surface sputtering. Micrographs were recorded at different magnifications to investigate both the surface coverage and the morphologies of the crystals. The atomic composition was monitored using energy dispersive X-ray analysis (EDX) analysis at two different magnifications. Analyses at a low magnification were performed on a major part of the sample to describe a mean value of the atomic composition. Two samples were analysed from each surface preparation and immersion time and the mean value was calculated.

\section{X-ray photoelectron spectroscopy}

For the X-ray photoelectron spectroscopy (XPS) analyses a PHI 5000C Perkin Elmer instrument equipped with a monochromatic Al $\mathrm{K} \alpha \mathrm{X}$-ray source operating at $200 \mathrm{~W}$ was used. Each sample was analysed at two separate positions and two samples were analysed from each surface preparation and immersion time and the mean value was calculated.

\section{Statistical analysis}

Calculations of group means and standard deviations for each surface preparation and time point was performed.

The parametric comparative analysis of differences of the group means was performed with STATA (13 edition) and ANOVA, Bartlett's test for equal variance test. Statistical significance was defined at $P \leq 0.05$.

\section{RESULTS \\ Surface analysis Topographical characterization}

All surface roughness results are displayed in Table 1. $S_{a}$ mean values: The control surface (B, blasted only) had higher mean values compared to the other surface preparations. The oxidised surface had the lowest mean values. The mean value of all surface preparations increased drastically after 2 weeks of immersion.

$S_{d s}$ mean values: Higher mean values were demonstrated for all surface preparations compared to the control surface. All surfaces showed highest mean values after two weeks.

$S_{d r}$ mean values: Similar mean values were presented after $24 \mathrm{~h}$ and 3 days. After 1 week the fluoridated surface had a mean value more than $50 \%$ higher compared to the other surfaces. 
Table 1. Topographical results as measured with an optical interferometry

\begin{tabular}{|c|c|c|c|c|}
\hline Immersion time & Surface & $\mathrm{S}_{\mathrm{a}}(\mu \mathrm{m})$ & $\mathrm{S}_{\mathrm{ds}}\left(\mathrm{x} 10^{3} \mathrm{~mm}^{-2}\right)$ & $S_{d r}(\%)$ \\
\hline \multirow{5}{*}{ Control } & $\mathrm{B}$ & $1.09(0.06)$ & $142(3)$ & $56.6(4.8)$ \\
\hline & $\mathrm{Ox}$ & $0.55(0.36)$ & $212(15)$ & $34.1(23.6)$ \\
\hline & $\mathrm{F}$ & $0.98(0.05)$ & $176(8)$ & $50.8(3.1)$ \\
\hline & HA & $1.03(0.08)$ & $171(13)$ & $58.2(4.9)$ \\
\hline & $\mathrm{AH}$ & $0.97(0.08)$ & $243(12)$ & $72.8(9.1)$ \\
\hline \multirow{5}{*}{24 hours } & $\mathrm{B}$ & $1.07(0.14)$ & $142(3)$ & $58.4(20.1)$ \\
\hline & $\mathrm{Ox}$ & $1.03(0.05)$ & $191(4)$ & $70.3(5.4)$ \\
\hline & $\mathrm{F}$ & $1(0.03)$ & $181(4)$ & $52.3(3)$ \\
\hline & HA & $1.03(0.07)$ & $161(3)$ & $53.3(3.6)$ \\
\hline & $\mathrm{AH}$ & $0.98(0.04)$ & $244(7)$ & $70.2(4.1)$ \\
\hline \multirow{5}{*}{3 days } & $\mathrm{B}$ & $1.41(0.61)$ & $181(11)$ & $93(53.4)$ \\
\hline & $\mathrm{Ox}$ & $1.17(0.46)$ & $211(12)$ & $99.8(55.2)$ \\
\hline & $\mathrm{F}$ & $1.17(0.46)$ & $200(24)$ & $57.5(3.4)$ \\
\hline & HA & $1(0.06)$ & $160(5)$ & $51.9(4.4)$ \\
\hline & $\mathrm{AH}$ & $1(0.03)$ & $250(8)$ & $80(3.8)$ \\
\hline \multirow{5}{*}{1 week } & $\mathrm{B}$ & $1.86(1.13)$ & $174(11)$ & $104.6(67.9)$ \\
\hline & $\mathrm{Ox}$ & $0.97(0.56)$ & $230(18)$ & $93.1(72.1)$ \\
\hline & $\mathrm{F}$ & $1.88(0.88)$ & $216(7)$ & $171.4(126.2)$ \\
\hline & HA & $1.08(0.06)$ & $172(9)$ & $70.8(11.2)$ \\
\hline & $\mathrm{AH}$ & $1.03(0.05)$ & $233(4)$ & $75.2(5.8)$ \\
\hline \multirow{5}{*}{2 weeks } & $\mathrm{B}$ & $6.78(1.52)$ & $229(78)$ & $992(340.3)$ \\
\hline & $\mathrm{Ox}$ & $4.79(1.25)$ & $284(12)$ & $766.6(179.2)$ \\
\hline & $\mathrm{F}$ & $6.58(0.94)$ & $272(9)$ & $762.2(169.5)$ \\
\hline & HA & $5.55(1.3)$ & $256(9)$ & $806.1(215)$ \\
\hline & $\mathrm{AH}$ & $6.56(1.34)$ & $272(9)$ & $1002.3(323.9)$ \\
\hline
\end{tabular}

The table presents mean values. Standard deviations are presented within parenthesis. Control - no immersion.

$\mathrm{B}=$ blasted (the control surface); $\mathrm{Ox}=$ anodically oxidised; $\mathrm{F}=$ fluoridated; $\mathrm{HA}=$ hydroxyapatite coated; $\mathrm{AH}=$ alkali and heat treated .

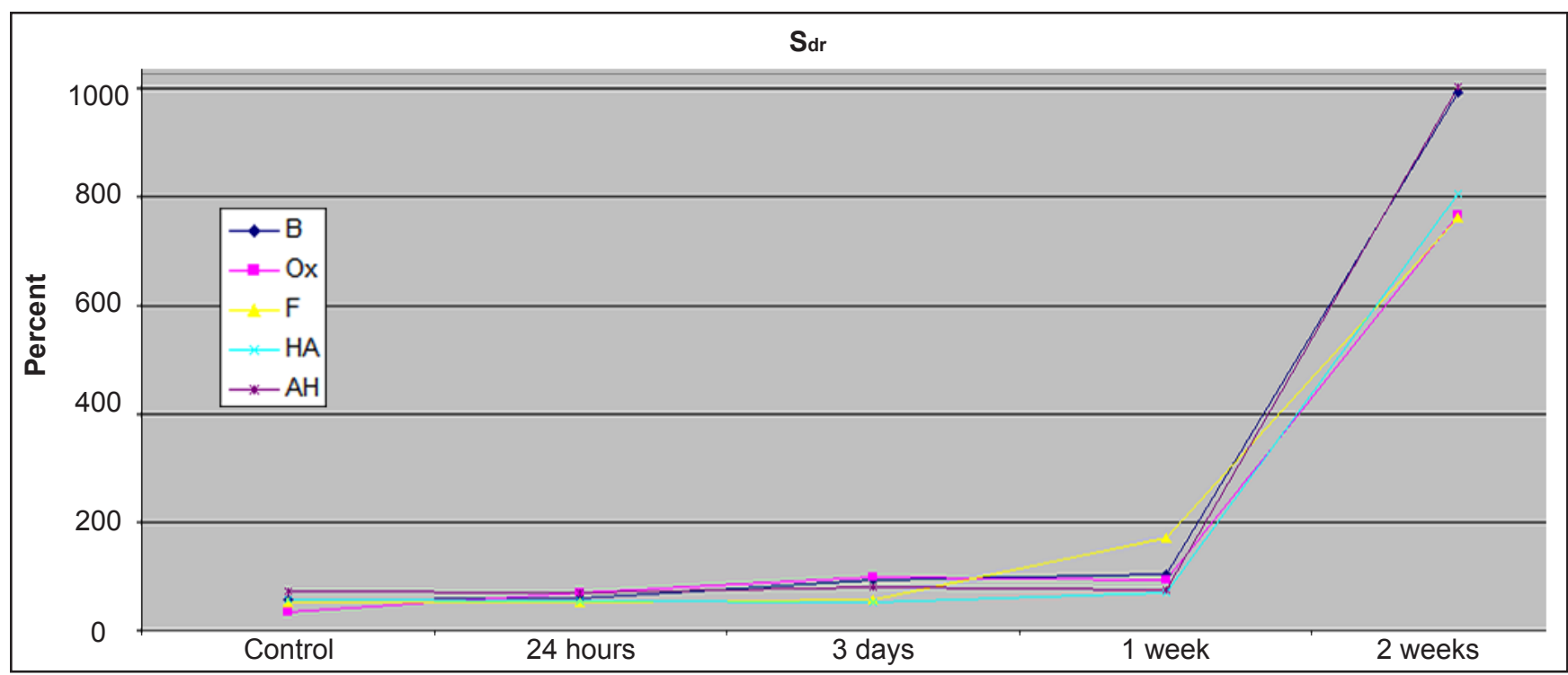

Figure 1. Mean values of $S_{\mathrm{dr}}$ after various immersion times.

$\mathrm{B}=$ blasted; $\mathrm{Ox}=$ anodically oxidised; $\mathrm{F}=$ fluoridated; $\mathrm{HA}=$ hydroxyapatite coated; $\mathrm{AH}=$ alkali and heat treated.

However, after two weeks the fluoridated surface showed the lowest mean value. All mean values increased with more than $600 \%$ after two weeks of immersion, but only the alkali and heat treated surface (AH) SEM images were recorded at several had a higher mean value than the control (Figure 1). magnifications, ranging from 70 to 20000 . 
As can be seen in Figure 2, the different surfaces used in this study exhibit large differences in surface morphology. However, from the SEM images no conclusion can be drawn concerning nucleating capacity. All surfaces show small precipitates after 3 days which with longer immersion times increase. After two weeks all surfaces are fully covered as shown in Figure 3.
EDX

The element analysis indicated high levels of titanium for all surfaces at baseline. With increasing time of immersion, a decreased amount of titanium and increased coverage of phosphate, calcium and carbon was observed. The calcium content was higher on the fluoridated as well as alkali and heat treated
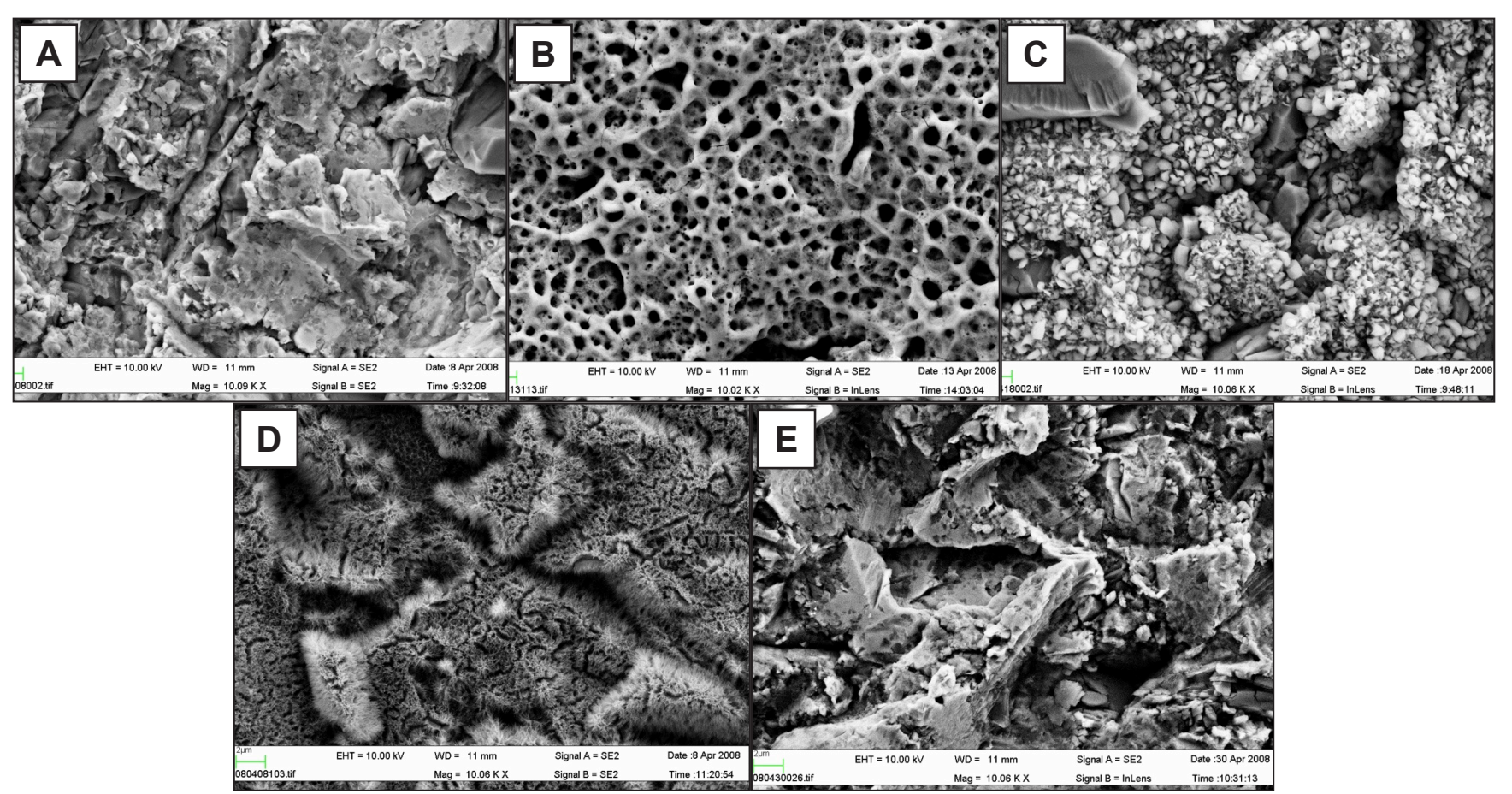

Figure 2. SEM images of different titanium surfaces. $\mathrm{Bar}=10 \mu \mathrm{m}$.

$\mathrm{A}$ = blasted; $\mathrm{B}=$ anodically oxidised; $\mathrm{C}$ = fluoridated; $\mathrm{D}=$ hydroxyapatite coated; $\mathrm{E}=$ alkali and heat treated.
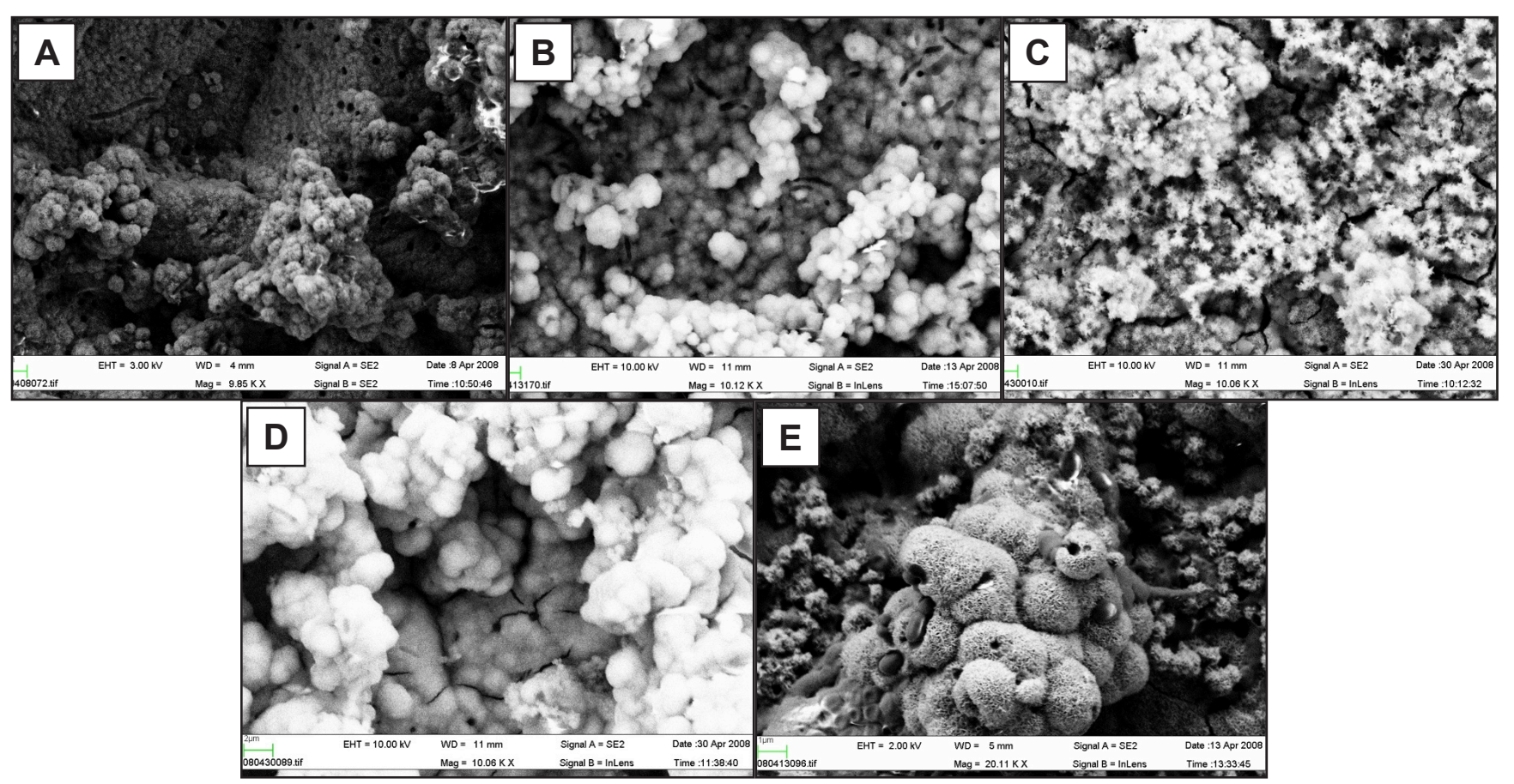

Figure 3. SEM images of different titanium surfaces after 2 weeks. Bar $=10 \mu \mathrm{m}$.

$\mathrm{A}=$ blasted; $\mathrm{B}=$ anodically oxidised $\mathrm{C}=$ fluoridated $\mathrm{D}=$ hydroxylapatite coated $\mathrm{E}=$ alkali and heat treated. 
samples at all time points, as compared to the other surface preparations. For the fluoridated samples, the difference was statistically significant $(\mathrm{P} \leq 0.05)$ after 1 week (Figure 4).

\section{XPS}

The analysis indicated increased amounts of calcium with increasing time however, the differences were insignificant (Figure 5). The mean $\mathrm{Ca} / \mathrm{P}$ ratio was significantly higher for the fluoridated samples (Figure 6) after $24 \mathrm{~h}$ and 3 days compared to the mean value of the other surface treatments $(\mathrm{P}<0.05)$. After 1 and 2 weeks the $\mathrm{Ca} / \mathrm{P}$ ratios varied between 1 and 1.5 (Figure 6). The titanium coverage decreased on all samples with time (Figure 7). The nitrogen levels increased with time and were inversely related to the $\mathrm{Ca} / \mathrm{P}$ ratio (Figure 8 ).

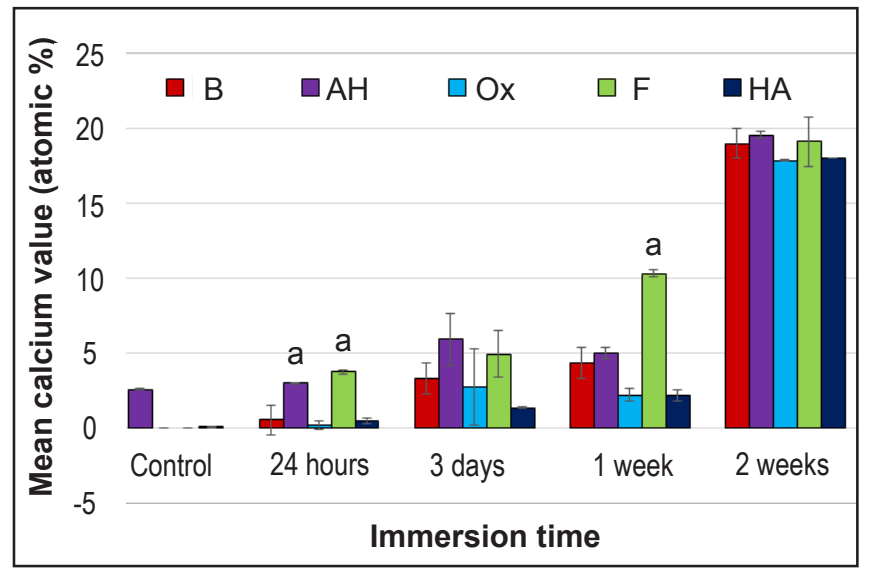

Figure 4. Mean values of calcium content on the different surfaces measured by EDX analysis.

$\mathrm{B}=$ blasted; $\mathrm{AH}=$ alkali and heat treated; $\mathrm{Ox}=$ anodically oxidised; $\mathrm{F}=$ fluoridated; $\mathrm{HA}=$ hydroxyapatite coated.

aStatistically significant at level $\mathrm{P} \leq 0.05$, Bartlett's test.

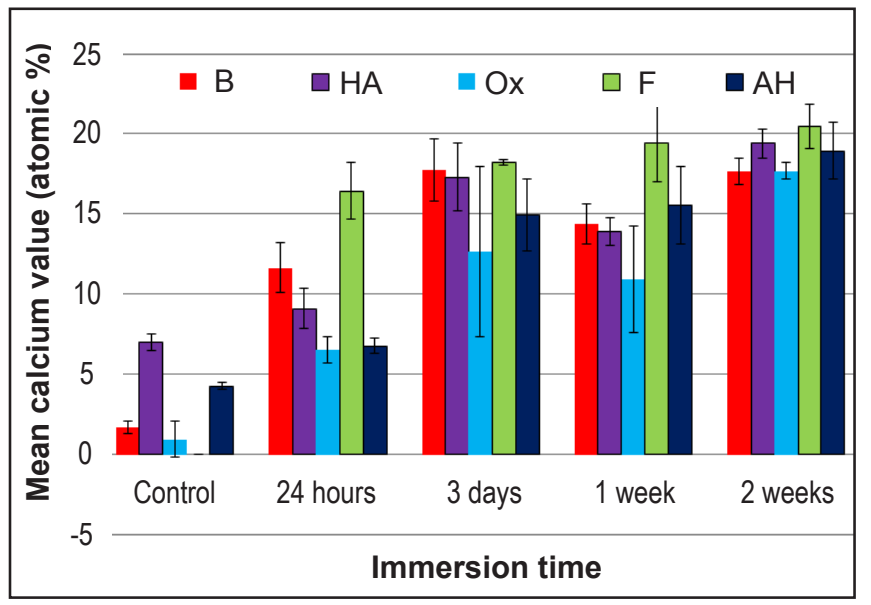

Figure 5. Mean values of calcium content on the different surfaces measured by XPS analysis.

$\mathrm{B}$ = blasted; $\mathrm{HA}=$ hydroxyapatite coated; $\mathrm{Ox}$ = anodically oxidised; $\mathrm{F}=$ fluoridated $\mathrm{AH}=$ alkali and heat treated.

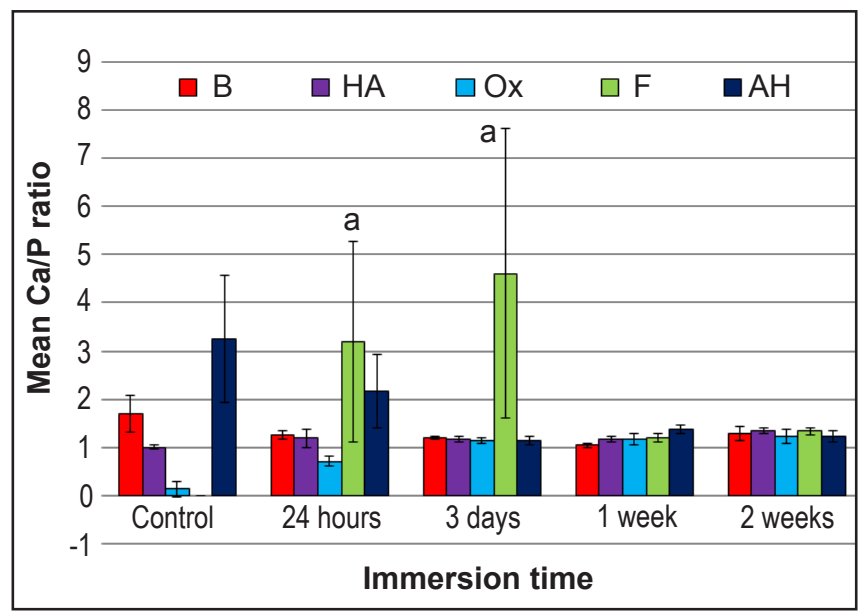

Figure 6. Mean values of $\mathrm{Ca} / \mathrm{P}$ ratio on the fluoridated discs measured by XPS analysis.

$\mathrm{B}$ = blasted; $\mathrm{HA}=$ hydroxyapatite coated $\mathrm{Ox}$ = anodically oxidised; $\mathrm{F}=$ fluoridated; $\mathrm{AH}=$ alkali and heat treated.

${ }^{\text {aS }}$ Statistically significant at level $\mathrm{P} \leq 0.05$, Bartlett's test.

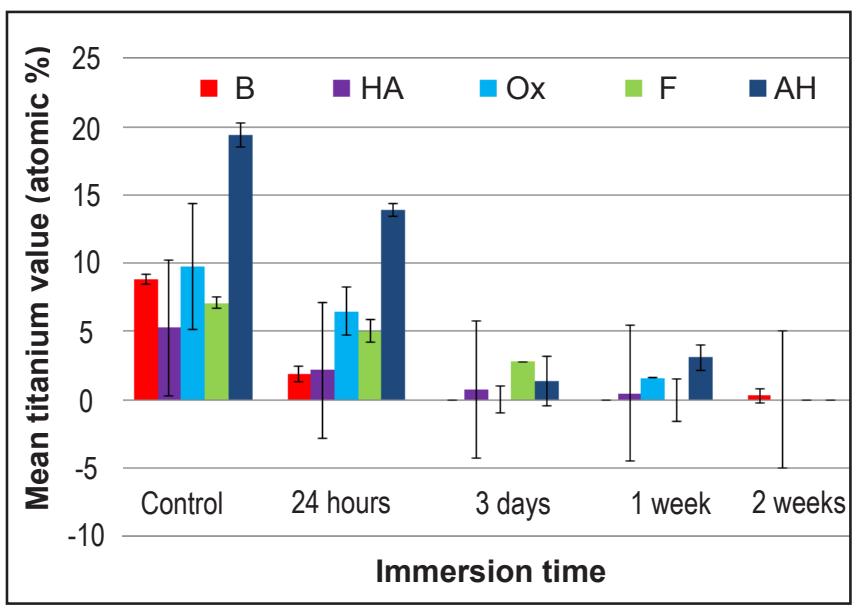

Figure 7. Mean values of titanium content on the different surfaces measured by XPS analysis.

$\mathrm{B}=$ blasted; $\mathrm{HA}=$ hydroxyapatite coated $; \mathrm{Ox}=$ anodically oxidised; $\mathrm{F}=$ fluoridated $\mathrm{AH}=$ alkali and heat treated.

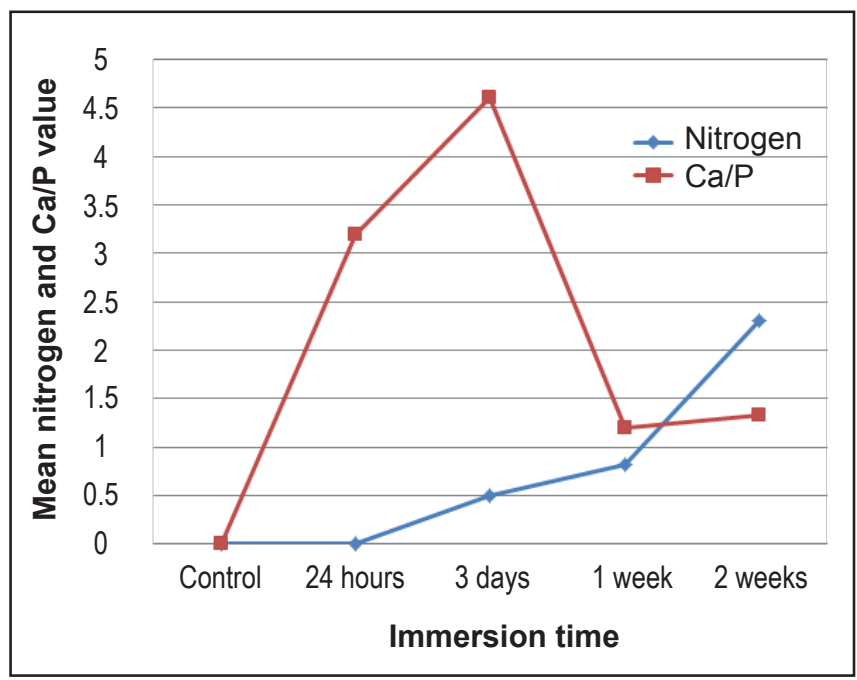

Figure 8. Mean values of nitrogen and $\mathrm{Ca} / \mathrm{P}$ on the fluoridated discs measured by XPS analysis. 


\section{DISCUSSION}

In the present study the formation of calcium phosphates on titanium implants with various surface preparations claimed to be bioactive, was investigated with the same settings in an SBF model with the addition of collagen type I solution.

Previously, the precipitation of calcium phosphates on surfaces has been studied in vitro using a variety of solutions, including SBF with varying compositions. In the present study a revised SBF [37] was chosen with an electrolyte concentration very similar to that of human plasma [39]. Regardless of the buffer used, it should be stressed that it is a simplified model for the conditions in vivo. However, a simplified model can facilitate the understanding of the initial phase of bone formation around titanium implants.

Furthermore, during bone formation in vivo there is a circulation of blood. Studies have been performed comparing results from dynamic and static SBF models, and it was found that less calcium phosphate material was formed with the dynamic model than the static model [40]. Lu and co-workers [40] also found that the surface topography influence was larger in the dynamic model than in the static model. In the present study a static SBF model was used. However, the buffer was changed after one week to avoid ion depletion and all specimens were treated according to the same protocol.

Wound healing around titanium implants is initiated by bleeding from the wound. As blood comes in contact with an implant surface it absorbs ions and proteins [41]. After a few days a fluid phase is built up around the implant, as shown by in vivo bone remodelling studies. It has been reported that the initial fluid phase decreases with time and is replaced by tissue [42-44]. An in vivo model in rabbit bone $[\underline{45}, \underline{46}]$ demonstrated that after four to six weeks bone growth occurs along the upper and lower parts of the implant surface. The immersion times used in the present study were selected to cover the initial phase in wound healing around the implant and additionally to follow the precipitation events.

Results from the topographical analysis, using the optical interferometer, showed an increase of the surface area $\left(\mathrm{S}_{\mathrm{dr}}\right)$ and vertical height of the irregularities $\left(\mathrm{S}_{\mathrm{a}}\right)$ after two weeks of immersion for all surface preparations. The control surface and the alkali heat treated surface demonstrated the highest mean height values $\left(\mathrm{S}_{\mathrm{a}}\right)$.

The precipitation of calcium phosphate on the different surface preparations was demonstrated by means of the SEM/EDX and XPS analysis. Results from the SEM/EDX analysis showed a higher $\mathrm{Ca} / \mathrm{P}$ ratio on the fluoridated discs than on the other surfaces (Figure 4). After one week of immersion there was a significantly higher degree of calcium precipitate on the fluoridated specimens (Figure 5) as compared to the other surfaces. Alkali and heat treated samples showed a higher $\mathrm{Ca} / \mathrm{P}$ ratio at baseline (Figure 6), but showed a lower mean $\mathrm{Ca} / \mathrm{P}$ ration compared to the other surfaces with prolonged immersion time.

The XPS analysis of the fluoridated discs indicated an inverted correlation between nitrogen content and $\mathrm{Ca} / \mathrm{P}$ ratio (Figure 8), where the increasing nitrogen content has been interpreted as an increased amount of proteins on the surface [47].

The titanium signal measured by XPS analysis (Figure 7) decreased on all surfaces with immersion time and after 2 weeks all titanium surfaces were completely coated and showed small amounts of detectable titanium. In earlier studies there was a higher titanium signal from titanium surfaces after two weeks in SBF without proteins [23], or with albumin [24] or fibrinogen [25], which indicates that collagen promotes precipitation of calcium phosphates. In all studies the same surface preparations were included.

The collection of data during a period of two weeks was not sufficient to determine whether the crystal growth had reached a limit i.e. a $\mathrm{Ca} / \mathrm{P}$ ratio value of approximately 1.67. Thus, an extension of the immersion time with an addition of at least four weeks might have given more information about the crystallinity over time. However, compared to previous SBF studies [23-25], the $\mathrm{Ca} / \mathrm{P}$ ratios after 1 and 2 weeks are relatively low in the present study (Figure 6), indicating a low degree of crystallinity. For example, after 1 week immersion in SBF without proteins, the $\mathrm{Ca} / \mathrm{P}$ ratio of blasted titanium surfaces was reported to be approximately 1.7 [23]. In the present study, corresponding $\mathrm{Ca} / \mathrm{P}$ ratio was measured to approximately 1 after immersion in SBF with addition of collagen type I (Figure 6).

Within the limitations of this simplified model, it is possible to study the influence of different proteins on calcium phosphates formation. Enhanced understanding of the interactions between different surface preparations and bone formation mechanisms can contribute to the further development of surface preparations that may improve the clinical outcome of bone anchored implants. 


\section{CONCLUSIONS}

In this study we have described a method to coat various titanium surfaces with $\mathrm{Ca} / \mathrm{P}$ and collagen type I. The results indicated that a fluoridated titanium surface may favour precipitation of $\mathrm{Ca} / \mathrm{P}$ in the presence of collagen type I as compared to the other surface treatments of the present study.

\section{ACKNOWLEDGMENTS AND DISCLOSURE STATEMENTS}

The authors thank the Sylvan research fund, Hjalmar Svensson Research Foundation, the Wilhelm and Martina Lundgren Science Foundation, and the Royal Society of Arts and Sciences in Göteborg for supporting the study with grants.

\section{REFERENCES}

1. Albrektsson T, Wennerberg A. Oral implant surfaces: Part 1--review focusing on topographic and chemical properties of different surfaces and in vivo responses to them. Int J Prosthodont. 2004 Sep-Oct;17(5):536-43. [Medline: 15543910]

2. Wennström JL, Heijl L, Lindhe J. Periodontal surgery: access therapy. In: Lindhe J, Karring T, Lang NP, editors. Clinical Periodontology and Implant Dentistry. 4th ed. Copenhagen: Blakwell Munksgaard. 2003. p. 815.

3. Hench LL. Bioactive glasses and glass ceramics: a perspective. In: Yamamuro T, Hench LL, Wilson-Hench J, editors. Handbook of bioactive ceramics. Vol 1. Florida: CRC press, Boca Raton. 1990. p. 7.

4. Göransson A. On possibly bioactive CP titanium implant surfaces [dissertation]. Göthenburg: Göthenburg University; 2006. [URL: http://hdl.handle.net/2077/16977]

5. Yan WQ, Nakamura T, Kobayashi M, Kim HM, Miyaji F, Kokubo T. Bonding of chemically treated titanium implants to bone. J Biomed Mater Res. 1997 Nov;37(2):267-75. [Medline: 9358321] [doi: 10.1002/(SICI)1097-4636(199711)37:23.0.CO;2-B]

6. Skripitz R, Aspenberg P. Tensile bond between bone and titanium: a reappraisal of osseointegration. Acta Orthop Scand. 1998 Jun;69(3):315-9. [Medline: 9703411] [doi: 10.3109/17453679809000938]

7. obayashi M, Nakamura T, Tamura J, Kikutani T, Nishiguchi S, Mousa WF, Takahashi M, Kokubo T. Osteoconductivity and bone-bonding strength of high- and low-viscous bioactive bone cements. J Biomed Mater Res. 1999;48(3):265-76. [Medline: 10398030] [doi: 10.1002/(SICI)1097-4636(1999)48:33.0.CO;2-0]

8. Fröjd V, Franke-Stenport V, Meirelles L, Wennerberg A. Increased bone contact to a calcium-incorporated oxidized commercially pure titanium implant: an in-vivo study in rabbits. Int J Oral Maxillofac Surg. 2008 Jun;37(6):561-6. [Medline: 18346880] [doi: 10.1016/j.ijom.2008.01.020]

9. Gittens RA, Scheideler L, Rupp F, Hyzy SL, Geis-Gerstorfer J, Schwartz Z, Boyan BD. A review on the wettability of dental implant surfaces II: Biological and clinical aspects. Acta Biomater. 2014 Jul;10(7):2907-18. [Medline: 24709541] [PMC free article: 4103435$]$ [doi: $10.1016 /$ j.actbio.2014.03.032]

10. Shalabi MM, Gortemaker A, Van't Hof MA, Jansen JA, Creugers NH. Implant surface roughness and bone healing: a systematic review. J Dent Res. 2006 Jun;85(6):496-500. Review. Erratum in: J Dent Res. 2006 Jul;85(7):670. [Medline: 16723643] [doi: 10.1177/154405910608500603]

11. Kokubo T, Kushitani H, Sakka S, Kitsugi T, Yamamuro T. Solutions able to reproduce in vivo surface-structure changes in bioactive glass-ceramic A-W. J Biomed Mater Res. 1990 Jun;24(6):721-34. [Medline: 2361964] [doi: $10.1002 / \mathrm{jbm} .820240607]$

12. Peltola T, Pätsi M, Rahiala H, Kangasniemi I, Yli-Urpo A. Calcium phosphate induction by sol-gel-derived titania coatings on titanium substrates in vitro. J Biomed Mater Res. 1998 Sep 5;41(3):504-10. [Medline: 9659622] [doi: 10.1002/(SICI) 1097-4636(19980905)41:33.0.CO;2-G]

13. Takadama H, Kim HM, Kokubo T, Nakamura T. TEM-EDX study of mechanism of bonelike apatite formation on bioactive titanium metal in simulated body fluid. J Biomed Mater Res. 2001 Dec 5;57(3):441-8. [Medline: 11523039] [doi: 10.1002/1097-4636(20011205)57:33.0.CO;2-B]

14. Kim HM, Himeno T, Kawashita M, Lee JH, Kokubo T, Nakamura T. Surface potential change in bioactive titanium metal during the process of apatite formation in simulated body fluid. J Biomed Mater Res A. 2003 Dec 15;67(4):1305-9. [Medline: 14624517] [doi: 10.1002/jbm.a.20039]

15. Lu X, Leng Y. TEM study of calcium phosphate precipitation on bioactive titanium surfaces. Biomaterials. 2004 May;25(10):1779-86. [Medline: 14738841] [doi: 10.1016/j.biomaterials.2003.08.028]

16. Song WH, Jun YK, Han Y, Hong SH. Biomimetic apatite coatings on micro-arc oxidized titania. Biomaterials. 2004 Aug;25(17):3341-9. [Medline: 15020106] [doi: 10.1016/j.biomaterials.2003.09.103]

17. Barrere F, Snel MM, van Blitterswijk CA, de Groot K, Layrolle P. Nano-scale study of the nucleation and growth of calcium phosphate coating on titanium implants. Biomaterials. 2004 Jun;25(14):2901-10. [Medline: 14962569] [doi: 10.1016/j.biomaterials.2003.09.063]

18. Kim HM, Miyaji F, Kokubo T, Nakamura T. Effect of heat treatment on apatite-forming ability of Ti metal induced by alkali treatment. J Mater Sci Mater Med. 1997 Jun;8(6):341-7. [Medline: 15348733] [doi: 10.1023/A:1018524731409] 
19. Sul YT, Johansson C, Byon E, Albrektsson T. The bone response of oxidized bioactive and non-bioactive titanium implants. Biomaterials. 2005 Nov;26(33):6720-30. [Medline: 15975649] [doi: 10.1016/j.biomaterials.2005.04.058]

20. Ellingsen JE. Pre-treatment of titanium implants with fluoride improves their retention in bone. J Mater Sci: Mater Med. 1995 Dec;6(12):749-53. [doi: 10.1007/BF00134312]

21. Gottlander M, Albrektsson T, Carlsson LV. A histomorphometric study of unthreaded hydroxyapatite-coated and titaniumcoated implants in rabbit bone. Int J Oral Maxillofac Implants. 1992 Winter;7(4):485-90. [Medline: 1299644]

22. Kokubo T, Takadama H. How useful is SBF in predicting in vivo bone bioactivity? Biomaterials. 2006 May;27(15): 2907-15. [Medline: 16448693] [doi: 10.1016/j.biomaterials.2006.01.017]

23. Arvidsson A, Franke-Stenport V, Andersson M, Kjellin P, Sul YT, Wennerberg A. Formation of calcium phosphates on titanium implants with four different bioactive surface preparations. An in vitro study. J Mater Sci Mater Med. 2007 Oct;18(10):1945-54. [Medline: 17554602]

24. Stenport V, Kjellin P, Andersson M, Currie F, Sul YT, Wennerberg A, Arvidsson A. Precipitation of calcium phosphate in the presence of albumin on titanium implants with four different possibly bioactive surface preparations. An in vitro study. J Mater Sci Mater Med. 2008 Dec;19(12):3497-505. [Medline: 18622767] [doi: 10.1007/s10856-008-3517-z]

25. Arvidsson A, Currie F, Kjellin P, Sul YT, Stenport V. Nucleation and growth of calcium phosphates in the presence of fibrinogen on titanium implants with four potentially bioactive surface preparations. An in vitro study. J Mater Sci Mater Med. 2009 Sep;20(9):1869-79. [Medline: 19415230] [doi: 10.1007/s10856-009-3755-8]

26. Di Lullo GA, Sweeney SM, Korkko J, Ala-Kokko L, San Antonio JD. Mapping the ligand-binding sites and diseaseassociated mutations on the most abundant protein in the human, type I collagen. J Biol Chem. 2002 Feb 8;277(6): 4223-31. [Medline: 11704682] [doi: 10.1074/jbc.M110709200]

27. Marieb EN, Hoehn K. Biochemistry. In: Marieb EN, Hoehn K, editors. Human Anatomy \& Physiology. 6th ed. San Francisco: Benjamin Cummings; 2004. p. 50.

28. Cooper GM, Haussman RE. The cell surface. In: Cooper GM, Haussman RE, editors. The cell: a molecular approach. 3rd ed. Sunderland (MA): Sinauer Associates; 2004. p. 523-4.

29. Takeuchi Y, Nakayama K, Matsumoto T. Differentiation and cell surface expression of transforming growth factorbeta receptors are regulated by interaction with matrix collagen in murine osteoblastic cells. J Biol Chem. 1996 Feb

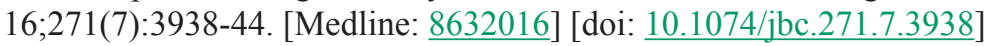

30. Marín-Pareja N, Salvagni E, Guillem-Marti J, Aparicio C, Ginebra MP. Collagen-functionalised titanium surfaces for biological sealing of dental implants: effect of immobilisation process on fibroblasts response. Colloids Surf B Biointerfaces. 2014 Oct 1;122:601-10. [Medline: 25115462] [doi: 10.1016/j.colsurfb.2014.07.038]

31. Takeuchi Y, Suzawa M, Kikuchi T, Nishida E, Fujita T, Matsumoto T. Differentiation and transforming growth factorbeta receptor down-regulation by collagen-alpha2beta1 integrin interaction is mediated by focal adhesion kinase and its downstream signals in murine osteoblastic cells. J Biol Chem. 1997 Nov 14;272(46):29309-16. [Medline: 9361011] [doi: $10.1074 /$ jbc.272.46.29309]

32. Roehlecke C, Witt M, Kasper M, Schulze E, Wolf C, Hofer A, Funk RW. Synergistic effect of titanium alloy and collagen type I on cell adhesion, proliferation and differentiation of osteoblast-like cells. Cells Tissues Organs. 2001;168(3):17887. [Medline: 11173803] [doi: 10.1159/000047833]

33. Rammelt S, Schulze E, Bernhardt R, Hanisch U, Scharnweber D, Worch H, Zwipp H, Biewener A. Coating of titanium implants with type-I collagen. J Orthop Res. 2004 Sep;22(5):1025-34. [Medline: 15304275] [doi: 10.1016/j.orthres.2004.02.011]

34. Kim HM, Miyaji F, Kokubo T, Nishiguchi S, Nakamura T. Graded surface structure of bioactive titanium prepared by chemical treatment. J Biomed Mater Res. 1999 May;45(2):100-7. [Medline: 10397963] [doi: 10.1002/(SICI)1097-4636(199905)45:23.0.CO;2-0]

35. Sul YT, Johansson CB, Jeong Y, Albrektsson T. The electrochemical oxide growth behaviour on titanium in acid and alkaline electrolytes. Med Eng Phys. 2001 Jun;23(5):329-46. [Medline: 11435147] [doi: 10.1016/S1350-4533(01)00050-9]

36. Sul YT, Johansson C, Wennerberg A, Cho LR, Chang BS, Albrektsson T. Optimum surface properties of oxidized implants for reinforcement of osseointegration: surface chemistry, oxide thickness, porosity, roughness, and crystal structure. Int J Oral Maxillofac Implants. 2005 May-Jun;20(3):349-59. [Medline: 15973946]

37. Oyane A, Kim HM, Furuya T, Kokubo T, Miyazaki T, Nakamura T. Preparation and assessment of revised simulated body fluids. J Biomed Mater Res A. 2003 May 1;65(2):188-95. [Medline: 2734811] [doi: 10.1002/jbm.a.10482]

38. Stout KJ, Sullivan PJ, Dong WP, Mainsah E, Luo N, Mathia T, Zahouani H. Development of methods for characterization of roughness in three dimensions. European Report EUR 15178 EN of commission of the European Communities. Brussels: Luxembourg and Authors; 1993.

39. Vander AJ, Sherman H, Luciano DS. Control of body movement. In: Vander AJ, Sherman H, Luciano DS, editors. Human physiology: the mechanisms of body function. 5th ed. New York: McGraw-Hill; 1990. p. 349.

40. Lu X, Leng Y, Zhang X, Xu J, Qin L, Chan CW. Comparative study of osteoconduction on micromachined and alkalitreated titanium alloy surfaces in vitro and in vivo. Biomaterials. 2005 May;26(14):1793-801. [Medline: 15576153] [doi: 10.1016/j.biomaterials.2004.06.009] 
41. Courtney JM, Lamba NM, Sundaram S, Forbes CD. Biomaterials for blood-contacting applications. Biomaterials. 1994 Aug;15(10):737-44. [Medline: 7986936] [doi: 10.1016/0142-9612(94)90026-4]

42. Eriksson A, Ericsson LL, Thomsen P, Lindblad R. Distribution of cells in soft tissue and fluid space around hollow and solid implants in the rat. J Mater Sci Mater Med. 1994 May; 5(5):269-78. [doi: 10.1007/BF00122396]

43. Rosengren A, Johansson BR, Danielsen N, Thomsen P, Ericson LE. Immunohistochemical studies on the distribution of albumin, fibrinogen, fibronectin, IgG and collagen around PTFE and titanium implants. Biomaterials. 1996 Sep;17(18):1779-86. [Medline: 8879516] [doi: 10.1016/0142-9612(95)00358-4]

44. Masuda T, Salvi GE, Offenbacher S, Felton DA, Cooper LF. Cell and matrix reactions at titanium implants in surgically prepared rat tibiae. Int J Oral Maxillofac Implants. 1997 Jul-Aug;12(4):472-85. [Medline: 9274076]

45. Sennerby L, Thomsen T, Ericson LE. Early tissue response to titanium implants inserted in rabbit cortical bone. Part I: Light microscopic obserrvations. J Mater Sci Mater Med. 1993 May; 4(3):240-50. [doi: 10.1007/BF00122275]

46. Sennerby L, Thomsen T, Ericson LE. Early tissue response to titanium implants inserted in rabbit cortical bone. Part II: Ultrastructural observations. J Mater Sci Mater Med. 1993 Sep; 4(5):494-502. [doi: 10.1007/BF00120129]

47. Zeng H, Chittur KK, Lacefield WR. Analysis of bovine serum albumin adsorption on calcium phosphate and titanium surfaces. Biomaterials. 1999 Feb;20(4):377-84. [Medline: 10048411]

\section{To cite this article:}

Stenport VF, Olander J, Kjellin P, Currie F, Sul YT, Arvidsson A.

Precipitation of Calcium Phosphates in the Presence of Collagen Type I on Four Different Bioactive Titanium Surfaces: an in Vitro Study

J Oral Maxillofac Res 2015;6(4):e1

URL: http://www.ejomr.org/JOMR/archives/2015/4/e1/v6n4e1.pdf

doi: $10.5037 /$ jomr.2015.6401

Copyright (C) Stenport VF, Olander J, Kjellin P, Currie F, Sul YT, Arvidsson A. Published in the JOURNAL OF ORAL \& MAXILLOFACIAL RESEARCH (http://www.ejomr.org), 31 December 2015.

This is an open-access article, first published in the JOURNAL OF ORAL \& MAXILLOFACIAL RESEARCH, distributed under the terms of the Creative Commons Attribution-Noncommercial-No Derivative Works 3.0 Unported License, which permits unrestricted non-commercial use, distribution, and reproduction in any medium, provided the original work and is properly cited. The copyright, license information and link to the original publication on (http://www.ejomr.org) must be included. 